\title{
Profitability and Production Effieciency of Indigenous Tomato Cultivation among Farmers in Osun State, Nigeria
}

\author{
A. B. Sekumade And S.O. W Toluwase \\ Ekiti State University, Ado - Ekiti. Department Of Agric. Econs. And Extension Services.
}

\begin{abstract}
This study aimed at determining the profitability and production efficiency of indigenous tomatoes cultivation among farmers in Osun State, Nigeria. A multistage sampling technique was used to select respondents for the study. The first stage involved a purposive selection of a local government based on the volume of total production of tomato from this area. The second stage involves random selection of six communities within the local government and this is followed by random selection of twenty respondents from each of the selected communities with the aid of structured questionnaire. Analysis of the data was based on 111 questionnaire because 9 were discarded as a result of inconsistency. Based on the objective of the study, descriptive analysis, regression analysis and gross margin estimate were employed. The findings revealed that male dominated tomato farming in the study area and farming is the major occupation of the respondents. They were married and educated. They mainly derived the source of their funding from owners equity and obtained their land by rent, majority do not have extension contact and obtain from local market the seed used as planting material. The scale of operation is small and utilized both family and hired labour. The variables such as marital status, farming experience and transplanting of seedlings as methods of planting were statistically significant at $1 \%$ level. The net farm income was estimated to be \#439,500 indicating that tomato production is profitable in the study area. Also the cost benefit ratio is found to be 1.84 and the rate of return was found to be 0.83 implying that for every one naira invested in tomato, a profit of 83 kobo is realizable. Finally, capital is the major constraint facing the farmers as reported by $65.8 \%$ of the respondents. Among the recommendations include that extension agents should be provided and be sent to assist farmers in bridging information gap between research stations and the farmers as regard new innovations on the farm and the farmers should be encouraged to form cooperatives to enhance their access to credit facilities.
\end{abstract}

Key words: Profitability, Production, Efficiency, Indigenous, tomato and farmers.

\section{Introduction}

Agriculture contributes about $40 \%$ of the Gross Domestic Product (GDP) and provides $88 \%$ non-oil earnings. The agricultural GDP is made up of crops (85\%), livestock (10\%), fisheries (4\%) and forestry (1\%). More than $90 \%$ of this agricultural output is provided by small-scale farmers with less than two (2) hectares under cultivation (FAO, 2007). Agricultural sector has performed far below expectation in providing cheap and affordable food on the table of average Nigerian despite all the productive potentials in terms of land, labour and capital resources that are available in abundance, hence this has necessitated for an increased importation of agricultural products most especially food items to meet local demands. Agriculture is the mainstay of the Nigerian economy. It is characterized by a large number of small-scale farmers with small holdings ranging from 0.05 to 3.0 hectares of land area, low capitalization and low yield per hectare (Olayide, 1982). The rate of growth of Nigeria's food production has been very low. Food growth rate has been put at 2.65 percent and population growth rate at 3.2 percent, leaving a food deficit of 0.55 percent $(\mathrm{CBN}, 1999)$.

Inefficiency in the use of available resources according to Gani and Omonona (2009), has hindered increased food production hence low income among the farmers across the nation. Efficiency is very important to increased agricultural production. This is because the scope of agricultural production can be expanded and sustained by farmers through efficient use of resources. Liu and Zhuang (2000), argued that financial constraints affected technical efficiency because, besides the quantity of input used, the timing of input usage which is been affected by finance also influences the farm output.

Tomato is one of the most widely cultivated crops in the world. It is an important source of vitamins and an important cash crop for small and medium-scale farmers (ShankaraNaika et al, 2005). As an important source of Minerals, Vitamins and health acids, tomato (Lycopersicon esculentum) is one of the most important vegetable crops of Solanaceae grown universally with the production of 124.75 million tonnes per annum (FAO 2007).

Tomatoes (Lycopersicon esculentum) is commonly grown in the Northern part of Nigeria, but largely consumed in the south western states in which Osun State is one of them. It is pertinent to note that, in spite of the existence of favourable tropical climate for its production in South Western Nigeria, the scarcity and exorbitant price of the product necessitate an in - depth investigation into its profitability and production 
efficiency in the study area. Crude technology has made farming unattractive and tedious. The results are increased dependence on food importation, rising cost of food and raw material leading to a fall in the standard of living coupled with increase cost of production (CBN, 1999). As a result of the increasing demand for food by the population and an insufficient production to meet the demand, there has been sharp and frequent rises in food prices. This situation has necessitated the diversion of scarce foreign exchange to the importation of basic staple food items that could otherwise be produced locally.

The dream and expectation of any farmer is to use little resources to get the maximum profit possible. With the right and appropriate technology employed in the production process, high profit can be realized. The agricultural farmer employs different techniques to the resources in the best proportion with the best technology known to him, and he expects to get the highest yield possible.

In a bid to help farmers increase productivity, the focus is usually on whether farmers are using better and improved technologies. It is however necessary to investigate whether these farmers are even making maximum use of what is available to them in terms of inputs. Farmers might use resources rationally but not at the economic optimal level. As the aim of every agribusiness firm is to maximize profit while minimizing cost, it is pertinent to determine the efficiency of resource use. The key to food security for the farmers in this regard is to link the ability to produce and sell at sustained levels of production throughout the year. It is expected that livelihoods will improve if farmer gets financial assistance and good price coupled with the provision of irrigation and a processing factory to handle the excess fresh tomatoes.

How then do we increase production and increase profitability? For example, a tomato farmer cultivating 2 hectares of land and getting less than 50 baskets in a production harvest. His large family and friends will still have to feed from this, which leaves him with very little to sell and have profit. Nigeria is spending over N11 billion yearly in the importation of tomatoes, the Director General, Raw Materials Research and Development Council (RMRDC), disclosed this at the opening of a workshop on tomato juice processing and marketing in Gusau, Zamfara State. He said, the country's overdependence in the importation of tomatoes cost the huge sum and that the trend will continue until adequate domestic food processing and storage facilities are put in place. Using locally developed technologies at lower cost would enhance the production and value addition to the primary and secondary raw materials to meet the needs of the nation's industries.

Kibaara (2005), identified level of education, age of the household head and gender of the household head to be associated with technical efficiency. Kibaara (2005), also reported that access to credit, and off- farm income reduce technical inefficiency. Furthermore, Olayide and Heady (1982), opined that agricultural productivity as the index of the ratio of the value of total farm input to the value of the total inputs used in production. They went further into identifying the main objectives of any society as the attainment of optimal high level of living with a given amount of effort as any increase in the productivity of resources employed in production amounts to progress.

Awudu and Richard (2000) reported that efficiency increased with age until a maximum efficiency was reached. Ajibefun (2002), observed that education and membership of farm association were one of the most important factors increasing efficiency. Educational level and farming experience have been reported to have a positive and significant impact on technical efficiency while extension contact has also been reported to have a positive and significant relationship with efficiency (Imoudu and Toluwase 2005).

Net farm income is the difference between gross income (revenue) and total cost of production.(Olukosi and Erhabor, 2005). It is used to show the levels of costs, returns and net profit that accrue to farmers involved in production. The technique emphasizes the costs (fixed and variable cost) and returns of any production enterprise. Olukosi and Ogungbile (1989) have examined two major categories of costs involved in crop production. These are fixed and variable cost. Fixed costs (FC) refer to those costs that do not vary with the level of production or output while variable cost (VC) refers to those costs that vary with output. The total cost (TC) is the sum of total fixed cost (TFC) and total variable cost (TVC).

Several researchers have used Net farm income as a tool for determining the profitability of crop production. Ayinde et al. (2011), examined resource use efficiency and profitability of fluted pumpkin and found the net farm income to be 116,891.39 per hectare while Yusuf et al. (2008), assessed the profitability of Egusi melon under sole and intercropping systems in Okehi local government area of Kogi state of Nigeria and found out that the average net farm income per hectare for sole melon and two, three and four crop mixtures were $\$ 1,328.68, \$ 915.77, \$ 887.27$ and $\$ 414.57$ respectively; the total gross return per hectare for melon (pooled data) averaged $\$ 12,638.61$ while the total cost of production was $\$ 8838.74$ on the average and the total net farm income per hectare for both sole and mixed (pooled data) melon was $\$ 3799.00$ on the average, implying that Egusi melon production was profitable in the study area.

In view of the above, this study aims at looking at the resource use efficiency of indigenous tomato cultivation among farmers in the study area viz a viz the resource employed by farmers, the effects of socio economic factors and variety of seeds in respect to productivity and profitability. 
Objectives: The general objective of this study is to determine the profitability and production efficiency of indigenous tomato cultivation among farmers in the study area. The specific objectives include to:

- describe the socio - economic characteristics of tomato farmers in the study area.

- identify factors influencing farmer's productivity in the study area.

- assess the determinants of tomato output in the study area.

- determining the profitability of tomato production in the study area.

- examine major constraints to tomato production and its profitability.

\section{Methodology}

Study Area: The study was conducted in Osun State in South western Nigeria that is made up of three agro ecological zones, characteristics of some of the south western states of the federation. The state has 6 administrative zones and 30 local government area. The predominant farming system in the area is shifting cultivation with mixed cropping and crop rotation. (www. Midwelljournals.com). Osun is an inland state with a total land area of 9, $251 \mathrm{~km} 2$ and a population of 2,203,016 (NPC, 1991) 4,137,627 (estimate 2005). The state falls within $7030^{\prime} \mathrm{N} 4030^{\prime} \mathrm{E} / 7.50 \mathrm{~N} 4.50 \mathrm{E}$, and the vegetation is rainforest with some patches of Guinea savanna. It experiences approximately eight months (March - October) of bimodal rainfall and four months (November February) of dry season each year with slightly irregularity in the rainfall distribution yearly (Wikipedia, 2011). Weather data for Osun Sate was obtained from the meteorological stations of the Obafemi Awolowo University, Ile-Ife, located in the Centre of Osun.

It covers an area of approximately 14,875 square kilometers and bounded by Ogun, Kwara, Oyo and Ondo States in the South, North, West and East respectively. The state is blessed with a highly literate and articulate populace who constitute a virile and productive workforce. Traditionally, the people engage in agriculture and produce sufficient food and cash crops for domestic consumption and as inputs for agro allied industries and for export. A reasonable segment of the populace comprises traders and artisans. Other occupation include hand weaving, mat making, dying, soap making, wood carving among others. The land surface is generally undulating and descends from an altitude of over $450 \mathrm{~m}$ in Ijesa area to $150 \mathrm{~m}$ and below in the southern parts of the state. The soil belongs to the highly ferruginous, tropical red soil associated with basement complex rocks. The deep drained clay soils of the hills and slopes are very important because they provide the best soils for cocoa and coffee cultivation in the soil. The lighter loams are more suitable for cultivating the local food crops, such as yam, cassava and maize. All parts of the states had natural lowland tropical rainforest vegetation.

Sampling procedure: A multistage sampling technique was used to select respondents for the study. First, a local government was purposively selected based on the volume of tomato production. The second stage involved the random selection of six communities (Akinwande, Arugba Olota, Majoroku, Dede, Koko Osun, and Waasimi) from the selected LGA. This was followed by the random selection of 20 respondents from each of the selected communities. In all, a total of 120 respondents were selected and interviewed, however, 9 questionnaires were disregarded because of gross inconsistency in the answers of the affected respondents. At the end, 111 questionnaires were used for the analysis.

It is quite important to emphasize here that personal administration and collection of structured questionnaires were undertaken so that important and genuine information would be collected. In this case, oral interview, personal observations and estimations were applied.

Methods of Data Analysis: Based on the objectives of the study, descriptive analysis, gross margin and regression analysis were employed.

I Descriptive Analysis: This entails the use of statistical tools like tables e.g., percentages and frequency to analyze the socio economic characteristics of tomato farmers.

ii. Gross Margin techniques: This can be used to analyze the respective profit of the farmers. Gross margin is the difference between the sales and the production costs (excluding the overheads) or as the ratio of gross profit to sales revenue, usually in the form of percentage. A gross margin for an enterprise is its financial output minus its variable costs.

iii Regression Analysis: The ordinary least square multiple regression analytical method was used to study the relationships between variables that determine the size of returns to the business. This involves the use of production function model. The model stipulates the technical relationship between inputs and output in any production process. It is used to examine the degree of effects of changes in inputs on the output in agricultural production.

$\mathrm{Q}=\mathrm{f}\left(\mathrm{x}_{\mathrm{i}} \ldots \ldots \ldots \ldots \ldots \ldots \ldots \ldots \ldots \mathrm{x}_{\mathrm{n}}, \mathrm{ut}\right)-$ implicit production function

Where Q

$\mathrm{x}_{\mathrm{i}} \ldots \ldots \ldots \ldots \ldots \ldots \ldots \ldots \ldots \mathrm{x}_{\mathrm{n}}=$ Explanatory variables

$\mathrm{Ut}=\quad$ Error term

The above will be 'utilized explicitly through experimentation with four functional forms: 
Linear function: $Q=b_{0}+b_{1} X_{1}+b_{2} X_{2}+b_{3} X_{3}+b_{4} X_{4}+b_{5} X_{5}+b_{6} X 6+b_{7} X_{7}+b_{8} X_{8}+b_{9} X_{9}+b_{10} X_{10}+e_{t}$.

Where $\mathrm{X}_{1}=$ Age (yrs.)

$\mathrm{X}_{2} \quad=\quad$ Gender

$\mathrm{X}_{3} \quad=\quad$ Marital Status

$\mathrm{X}_{4} \quad=\quad$ Household Size

$\mathrm{X}_{5} \quad=\quad$ Educational Level

$\mathrm{X}_{6} \quad=\quad$ Farm Size

$\mathrm{X}_{7}=$ Years of farming experience

$\mathrm{X}_{8} \quad=\quad$ Seed Cost

$\mathrm{X}_{9} \quad=$ Labour Cost

$\mathrm{X}_{10}=$ Pesticide Cost

$\mathrm{X}_{11}=$ Fertilizer Cost

$\mathrm{X}_{12}=$ Transport Cost

$\mathrm{X}_{13}=$ Transplanting

$\mathrm{X}_{14}=$ Herbicide Cost.

$\mathrm{e}_{\mathrm{t}}=$ Error term

An aprior expectation of the variables relationship with respect to the aggregate quantity of output $(Q)$ is that the coefficients of the variables are expected to obey economic theories.

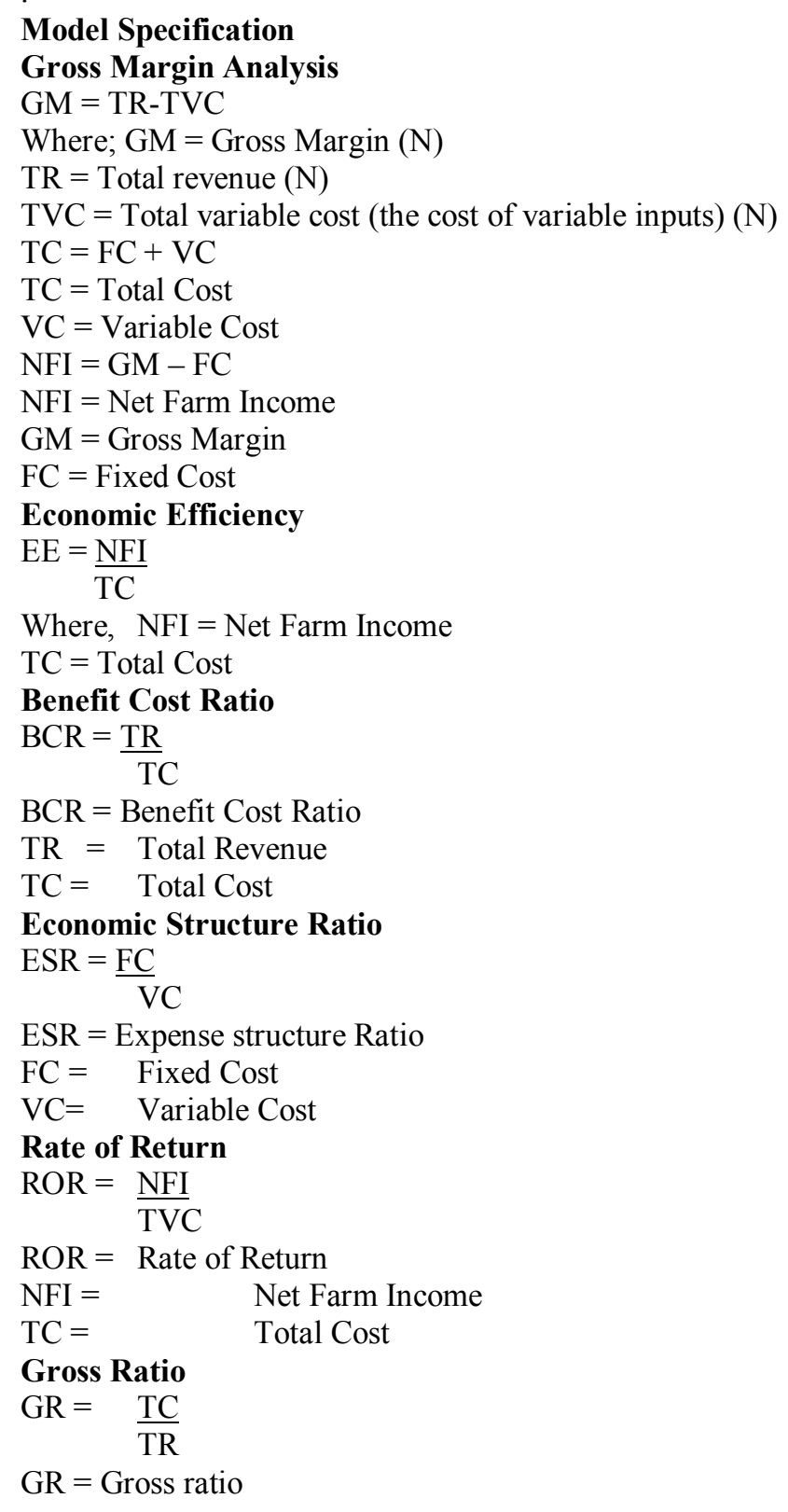


$\mathrm{TR}=$ Total Revenue

$\mathrm{TC}=$ Total Cost.

\section{Results and Discussion}

\section{Analysis of Socio- economic Characteristics of the Respondents.}

The socio economic characteristics of tomato famers in the study area are presented in the table 1 . The table revealed that $45.9 \%$ of tomato farmers were within the age of 20 - 30years, while above 60 years takes $18 \%$ of the total population sampled. The distribution shows that more than half of the respondents are within their active working age. The table also shows the gender distribution of tomato farmers. It was observed that in all the villages, farming are mainly the jobs of men with the majority (92.7\%) of tomato farmers are male while the remaining $7.3 \%$ are female. The table also show the distribution of family size among the farmers with the highest number of respondents belonging to those with the family size $1-3$ which represents $48.6 \%$ of the entire respondents while those with the family size of $7-9$ household size takes $11.7 \%$ of the farmers. The implication is that a lot of hired labour will be needed to supplement the insufficient family labour that they have; this in turn increases the production costs. The table also shows that $74.8 \%$ of the respondents are married and $25.2 \%$ are single. In subsistence agriculture, the higher the household size, the higher the labour and this will help the farmer to increase his size of production which will in turn increase production and profitability. The table also reflects the educational level of the respondents. From the table, $81 \%$ of the respondents have formal education ranging from primary to tertiary level. However, $18.0 \%$ has no formal education. It implies that since majority of the farmers are educated, it will improve the productivity and efficiency of tomatoes production in the study area. The farming experience of the farmers is expressed in the number of years the farmer has been into tomato production. It shows $48.6 \%$ of the farmers had been into tomato production in less than 10 years ago. Majority (51.4\%) has farming experience of 10 years and more and this implies that they have more experience of tomato production in the study area. The occupational distribution of the respondents can be drawn from the table likewise. From the table, 92.8 percent of the respondents are into farming; 2.7 percent are into trading; $1.8 \%$ are artisans; $0.9 \%$ are salary/ wage earners and $1.8 \%$ are student. This implies that a larger percentage engage in farming activities which simply means respondents have the best time to practice their farming resulting to an increase output and efficiency. This is supposed to have positive impact on output, ceteris paribus.

Table 1: Socio- economic Characteristics of the Respondents

\begin{tabular}{|c|c|c|c|}
\hline Variables & Years & Frequency & Percentage (\%) \\
\hline Age & $\begin{array}{l}20-30 \\
31-40 \\
41-50 \\
51-60 \\
\text { Above } 60 \\
\text { Total } \\
\end{array}$ & $\begin{array}{l}51 \\
32 \\
2 \\
6 \\
20 \\
111 \\
\end{array}$ & $\begin{array}{l}45.9 \\
28.9 \\
1.8 \\
5.4 \\
18.0 \\
100.0 \\
\end{array}$ \\
\hline Gender & $\begin{array}{l}\text { Male } \\
\text { Female } \\
\text { Total } \\
\end{array}$ & $\begin{array}{l}103 \\
08 \\
111 \\
\end{array}$ & $\begin{array}{l}92.7 \\
7.2 \\
100 \\
\end{array}$ \\
\hline Household size & $\begin{array}{l}1-3 \\
4-6 \\
7-9 \\
\text { Total }\end{array}$ & $\begin{array}{l}54 \\
44 \\
13 \\
111\end{array}$ & $\begin{array}{l}48.6 \\
39.6 \\
11.7 \\
100.0\end{array}$ \\
\hline Marital Status & $\begin{array}{l}\text { Single } \\
\text { Married } \\
\text { Total } \\
\end{array}$ & $\begin{array}{l}28 \\
83 \\
111 \\
\end{array}$ & $\begin{array}{l}25.2 \\
74.8 \\
100.0 \\
\end{array}$ \\
\hline Educational level & $\begin{array}{l}\text { No Formal educ. } \\
\text { Primary } \\
\text { Secondary } \\
\text { Tertiary } \\
\text { Total }\end{array}$ & $\begin{array}{l}20 \\
49 \\
27 \\
15 \\
111\end{array}$ & $\begin{array}{l}18.0 \\
44.1 \\
24.3 \\
13.5 \\
100\end{array}$ \\
\hline Farming Experience & $\begin{array}{l}<10 \\
10-19 \\
20-29 \\
30-39 \\
40-49 \\
50-59 \\
60 \text { and Above } \\
\text { TOTAL } \\
\end{array}$ & $\begin{array}{l}54 \\
31 \\
13 \\
8 \\
3 \\
1 \\
1 \\
111 \\
\end{array}$ & $\begin{array}{l}48.6 \\
27.9 \\
11.7 \\
7.2 \\
2.7 \\
0.9 \\
0.9 \\
100 \\
\end{array}$ \\
\hline Occupation & $\begin{array}{l}\text { Farming } \\
\text { Trading } \\
\text { Artisan } \\
\text { Salary/Wage earner } \\
\text { Student } \\
\text { Total }\end{array}$ & $\begin{array}{l}103 \\
3 \\
2 \\
1 \\
2 \\
0 \\
111\end{array}$ & $\begin{array}{l}92.8 \\
2.7 \\
1.8 \\
0.9 \\
1.8 \\
0.0 \\
100.0\end{array}$ \\
\hline
\end{tabular}

Source: Field Survey, 2012. 


\section{Factors Influencing Farmers Productivity}

The table 2 shows different factors influencing farmer's productivity. The table revealed that majority of the farmers employed 'Self Help' with the group taking $87.4 \%$ of the total respondent, ten (10) of the farmers belongs to cooperative society and four belongs to farmers Union. Membership of clubs, associations or cooperatives avails a farmer the opportunity of not only obtaining credit and agricultural inputs but also information on how to improve his farming techniques. The table reveals the various sources of seeds for planting. It is observed that majority $(91.9 \%)$ of farmers' obtain their seeds from local market, $3.6 \%$ got their seeds from research stations while $3.6 \%$ got their seeds from previous production. The output of those who obtained their seed from research stations had higher production and profit was very high despites their small hectare of land under cultivation denoting high quality of seeds from the source. The level of contact with the extension agents was very low as only $26.1 \%$ had contact with the change agents. When farmers are visited by extension agents through empowerment programmes and technological innovations, productivity will increase and profits will be high. The table shows that majority $(82.9 \%)$ of the farmers cultivated the local variety of tomato and only 17.1 percent of the farmer's cultivate the improved variety. This simply implies that farmer's interest in cultivating indigenous /local tomatoes is higher than the improved. This can be linked with the accessibility and awareness of the basic principles involved in the production of improved tomato and can also be related to the lack of extension visits as shown from the study. The table also indicates that 61.3 percent of the farmers are practicing traditional farming, while 9.0 percent practiced mechanical farming and $29.7 \%$ of the total respondents practiced both method of cultivation. The type of mechanical farming practiced can be likened to be a pseudo mechanical one because it's only during pre-planting operations that farmers engaged in mechanization like ridging, ploughing, harrowing and other pre-planting activities. The cropping pattern prevalent in Ayedaade LG as reflected in the table shows that 107 of the tomato farmers practice traditional pattern using mixed cropping pattern and only 4 out of the mixed farmers representing $3.6 \%$ practice sole cropping. 53 of the total respondents (107) practicing mixed farming i.e mixed their tomato cultivation with yam and another (16) respondents intercropped with cassava, pepper, melon, okra and leafy vegetable.

The table also reflects that $48.5 \%$ of the farmers had farm size of $3-5$ hectares, $45.9 \%$ had below 3 hectares and only $0.9 \%$ are large scale farmers cultivating between $9-10$ hectares. This implies that the community is blessed with large hectares of land that are accessible for farming, if harnessed efficiently, will boost productivity and profitability but tomato production in the study area is practiced mainly by small-scale farmers. The table also revealed that 36.8 percent planted their tomato around March and April, $46.8 \%$ planted in May - June, $16.2 \%$ planted in July - August and $0.9 \%$ of the farmers planted in October - December. The time of planting is a function of time of harvest provided other variables are constant. Majority of the farmers planted their crop during the raining season when they are very sure of the availability of rainfall hence majority of them planted at raining season leading to large production in the market except for few among them who planted at dry season using irrigation thereby leading to high profit because production is very scarce at this period.

The table equally shows that $36.0 \%$ of the farmers used family labour, $39.6 \%$ used hired labour and $24.3 \%$ used both. Education of family members most especially the children had reduces the use of family labour in recent time.

Table 2: Factors Influencing Farmers Productivity.

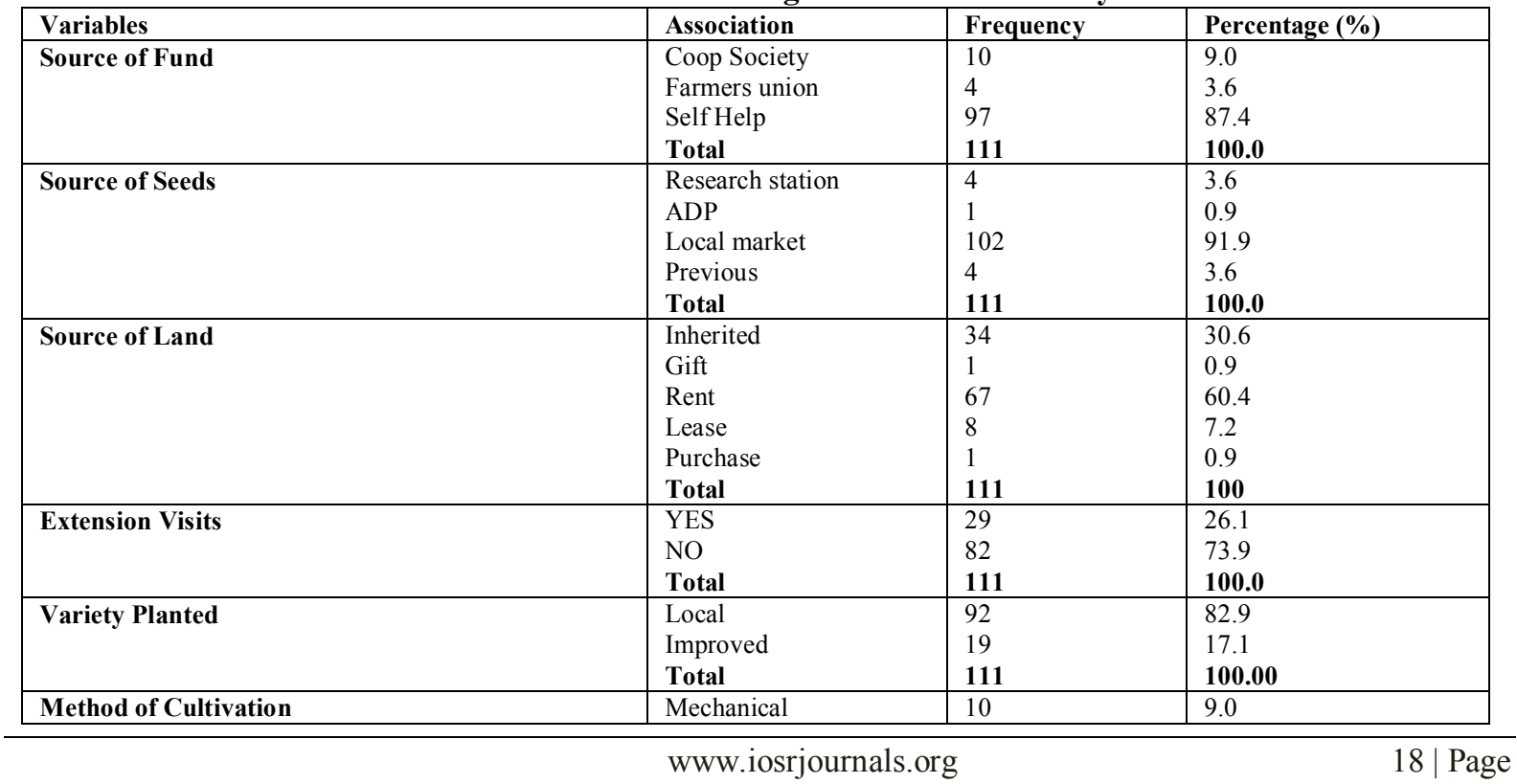


Profitability and Production Effieciency of Indigenous Tomato Cultivation among Farmers in ....

\begin{tabular}{|l|l|l|l|}
\hline & Traditional & 68 & 61.3 \\
& Both & 33 & 29.7 \\
& Total & $\mathbf{1 1 1}$ & $\mathbf{1 0 0 . 0}$ \\
\hline Cropping pattern & Sole & 4 & 3.6 \\
& Mixed & 107 & 96.4 \\
& Total & $\mathbf{1 1 1}$ & $\mathbf{1 0 0 . 0}$ \\
\hline Farm Size & $<3$ & 51 & 45.9 \\
& $3-5$ & 55 & 48.5 \\
& $>6$ & 5 & 5.4 \\
& Total & $\mathbf{1 1 1}$ & $\mathbf{1 0 0 . 0}$ \\
\hline Time of Planting & March - April & 40 & 36 \\
& May- June & 52 & 46.8 \\
& July- August & 18 & 16.2 \\
& October - Dec. & 1 & 0.9 \\
& Total & $\mathbf{1 1 1}$ & $\mathbf{1 0 0}$ \\
\hline Labour Used & Family & 40 & 36.0 \\
& Hired & 44 & 39.6 \\
& Both & 27 & 24.3 \\
& Total & $\mathbf{1 1 1}$ & $\mathbf{1 0 0}$ \\
\hline
\end{tabular}

Source: Field Survey, 2012.

\section{Determinants of Tomato Output.}

The variable $\mathrm{X}_{3}$ (Marital status) is statistically significant and positive at $1 \%$. This indicates that production is efficiently made when farmers are married as they will have more helping hands to support them on their farms. It can be deduced from this result that farmers should be encouraged to get married to increase their household size which will increase family labour and invariably increase output and profitability of farmers. The variable $X_{7}$ (farm experience) is statistically significant and positive at $1 \%$, revealing that farming experience is another major determinant in the productivity of the tomatoes farmers which will result to increase their income, implying that the greater the experienced gained, the greater the productivity of the farmers. This finding is in agreement with the findings by Ajibefun, Battese and Daramola (2002). The variable $X_{13}$ (Transplanting) is statistically significant and positive at $1 \%$. This implies that the farmers are aware that for them to have maximum output in the tomatoes production, they need to nurse them first before transplanting for optimum performance. This indicates that an increase in the transplanting of tomato seedlings will increase productivity as transplanted seedlings thrived well on soil than the seed planted in situ. The variable $\mathrm{X}_{10}$ (pesticide cost) is statistically significant at $5 \%$ and negative). This indicates that increase in the cost of pesticide reduced production and profitability will also be affected. It can be deduced from this that farmers make use of pesticide, but affects their profitability because cost of pesticide is an additional cost to variable costs of the production. Both cost of pesticide and the cost of application were found to be negatively related with efficiency. This indicates that farmers are not applying pesticides efficiently in tomato production. The variables $\mathrm{X}_{1}$ (Age), $\mathrm{X}_{2}$ (Gender), $\mathrm{X}_{4}$ (household size), $\mathrm{X}_{8}$ (Seed Cost), $\mathrm{X}_{11}$ (Fertilizer cost), and $\mathrm{X}_{14}($ Herbicide cost) are statistically not significant and positive while $\mathrm{X}_{6}$ (Farm size) and $\mathrm{X}_{12}$ (Transport cost) are statistically not significant and negative. The coefficient for age of household heads was not significant and positively correlated with Tomato output. This implies that age is not a barrier to tomato production in the study area since they are exposed to its practice from childhood and the soil is in good condition as they don't really depend on fertilizer application and not much technicality is involved and this can be deduced from the mean age (41) of farmers. This findings is in agreement with earlier studies by Imoudu and Toluwase (2005) which found that education enhances the ability of the farmers to acquire and make judicious use of information about production inputs, thus improving efficient use of the inputs. 
Table 3. Production Function analysis for tomato farmers in the study area.

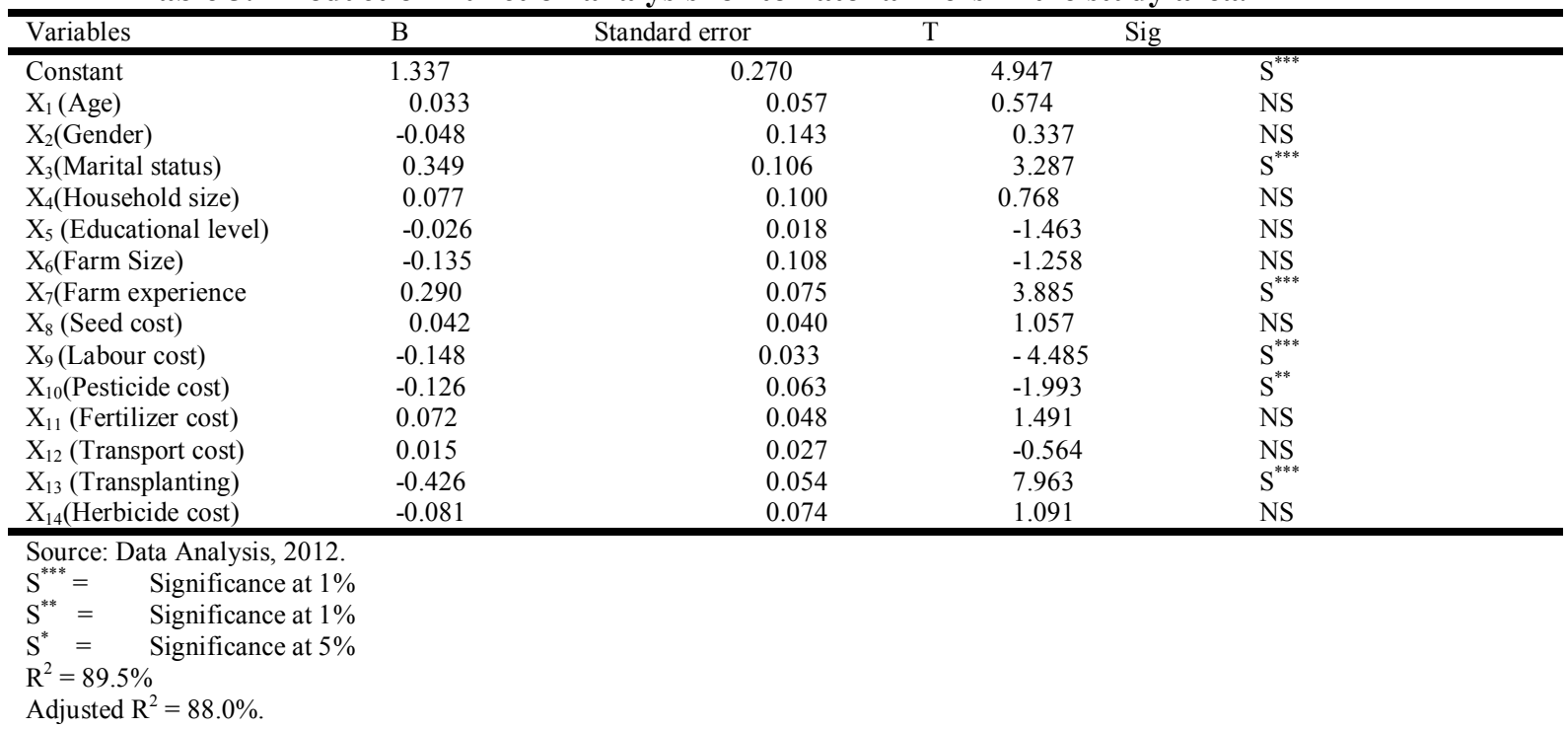

Determining the Profitability of Tomato Farmers in the study area.

Table 4. Showing the Costs and Revenues of Tomato Producer.

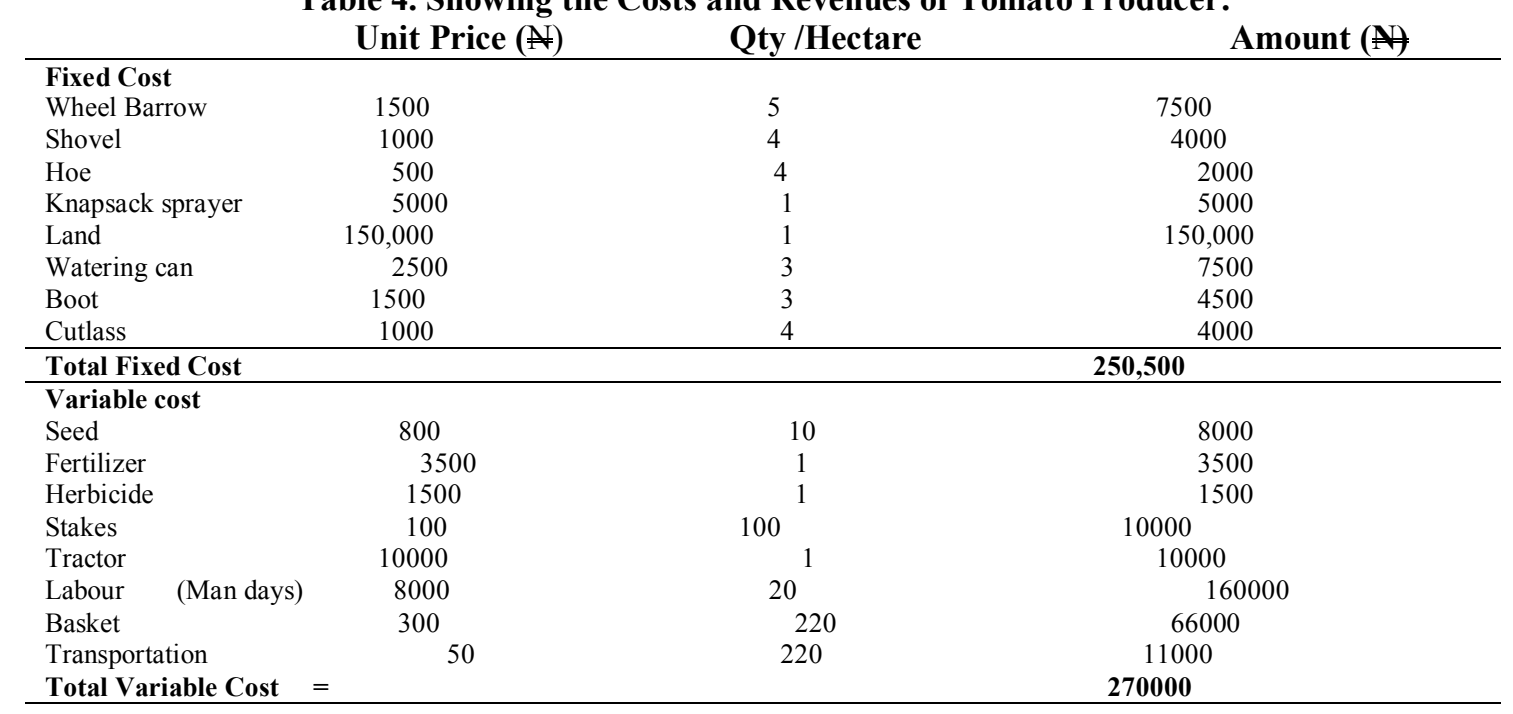

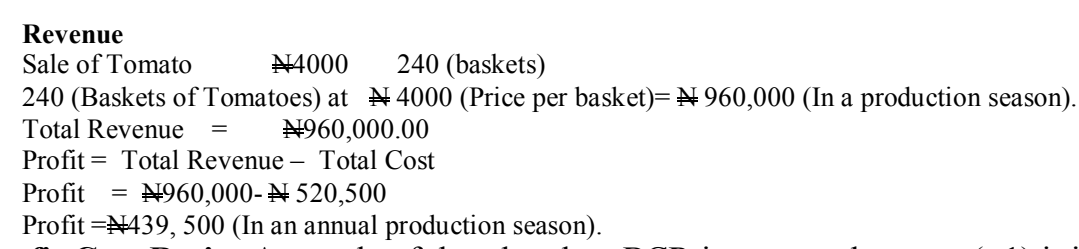

Benefit Cost Ratio: As a rule of thumb, when BCR is greater than one ( $>1)$ it indicates profit, when it is equal to 1 , it indicates break even and when it is $<1$, it indicates loss. Form the result above, BCR is 1.84 indicating profit.

Rate of Return: According to the result, the average rate of return per naira invested was 0.83 implying that for every one naira invested in tomato production there is a profit of 83 kobo. This indicates that tomato production is profitable in the study area.

Net Farm Income (NFI): According to the result, the Net Farm Income was calculated to be $\$ 439,500$ showing that tomato production is profitable, nevertheless there is room for improvement in tomato production as these accounts for the two production season in a year that the farmer can produced.

\section{Major Constraints in Tomato Production}

Table 5 reveals the problems that serve as major constraints to production by farmers in the study area. These constraints affect farmer's productivity and profitability. 
Capital: This is the major constraints $(65.8 \%)$ to tomato production in the study area. Other constraints include pest, labour, excessive rainfall, inadequate chemical, low market, poor soil fertility, health challenges of farmers, transportation of output and climate change among others.

The implication of these aforementioned constraints to productivity and profitability is that farmers efficiency in production will be low, as a result of insufficient capital to buy seeds, hire labour, clear land, purchase inputs such as chemicals (pesticides and herbicides), manures (organic or inorganic manure) and these limits farmers entrepreneurial skills and technological innovation to be actualized since there is no capital to purchase them. Also, farmer's farm size (hectares) will be reduced since they have no money to expand and manage effectively if increased.

Pest: A significant portion (11.7\%) of the farmers have pest as a major constraints in their productivity most especially in the recent years of 2-3 years, farmers that are visited by the extension agents reported that they had tried their best in eliminating or combating this problem of pest and diseases but all efforts proved abortive.

Availability of labour is important for timeliness of operations and for obtaining the desired output. The available hired labour in the study area are not sufficient, hence a problem. High transportation cost is a problem especially in the study area where roads are bad and petroleum products (petrol and diesel) are scarce and expensive. Market glut is equally a problem in marketing the produce especially when there is excess supply in the market during the raining season, which causes the price to fall.

Table 5: Major Constraints to Tomato Production.

\begin{tabular}{|l|l|l|}
\hline Major problems & Frequency & Percentage \\
\hline Pest & 13 & 11.7 \\
Capital & 73 & 65.8 \\
Labour & 13 & 11.7 \\
Excessive rainfall & 4 & 3.6 \\
Inadequate chemicals & 2 & 1.8 \\
Low market & 1 & 0.9 \\
Soil & 1 & 0.9 \\
Health challenges & 1 & 0.9 \\
Transportation & 1 & 0.9 \\
Climate change & 1 & 0.9 \\
Poor soil fertility & 1 & 0.9 \\
Total & 111 & 100.0 \\
\hline
\end{tabular}

Source: Field Survey, 2012.

\section{Conclusion}

It is clear that tomato farmers in the study area operates on small scale, their farms are too small in the presence of large hectares of land available for farmers. A lot of tomato farms cultivated less than 3 or equal to 3 hectares $(45.9 \%)$. Hence, the resultant averages yield.

Also, it can be observed from the work that most tomato farmers are youth within the age of $21-30$ which makes their family sizes to be relatively small, educational status and ability to cater for children were reasons why farmers have small family size. Hence, farmers hire labour which are being paid in man - days which are high and scarce most times and money is imputed which invariably reduce rate of returns of farmers after the production season.

The facts that the bulk of tomato farmers $(75 \%)$ are less than 40years. This accounts for high output obtained. The findings revealed that $60.4 \%$ of respondents are aware and utilize tractor and other farms inputs on their farms. Though, the use of inputs depends on how financially buoyant they are in that season. All these reflect the fact that major technical innovations are averagely getting to the grass roots and that diffusion rate is averagely okay. The research work shows that only few educated and reachable farmers have access to the extension agents. Other problems discovered in the study area include insufficient capital, pest, inadequate or insufficient labour, excessive rainfall, inadequate chemical, low market, soil fertility variation, farmer's health challenges, transportation, climate change etc. necessary inputs required by the farmers in the study area for maximum production are very limited and this led to low yield in their output.

Moreover, it was discovered that these farmers are not in any cooperative society which would have given them access to loan resulting to an increase in yields through increased farms size and ability to purchase technological inputs. The farmers do not receive financial assistance inform of credit from formal sources. They depend mostly on their personal savings. The Benefit cost ratio (BCR) calculated shows that farmers are making profit from their production.

From the foregoing, it can be clearly seen that much will be needed to improve on farmer's production if a sustainable agriculture is to be achieved. The increase and improvement will have to come from a breakthrough in productivity and increased efficiency in production.

Consequently, the level of production efficiency is strongly affected by the management ability of the individual farmer and also by the use of chemical input. Social factors such as household size, labour (nature, 
availability and quality), and level of education have direct and indirect effects on agricultural production. The farmers were inefficient in the use of resources. Seed, land, hired labour, fertilizer and pesticide were underutilized. Enough potential therefore exist for increased production of tomato in the study area. The findings of the study implies that financial institutions in the area should consider making loans available and accessible to the farmers so that they can afford to increase the use of the study area to educate the farmers to increase the use of land, hired labour and seed and also the right quantities of pesticide and fertilizer in order to boost production and profitability of the business.

\section{Recommendations}

Within the context of findings in this study, the following recommendations were made.

- To improve on production efficiency of tomato farmers, further promotion of rural household education, better access to credit facilities through improving rural financial markets, improvement in rural infrastructure (mainly roads) would be needed. It is advised that policy and opportunities that meets the need of the ideal situation of the farmers be established and not those that favour large scale farmers only. Given the low level of cash income that farmers have at their disposal, promoting micro finance institutions accessible to small farmers could make an immense role in the use of modern inputs. In addition, developing input markets, especially for fertilizer, herbicides and improve seeds is crucial.

- Government should allow and encourage full participation of private traders so as to improve the supply and distribution of inputs. If productivity must increase, farmers must improve their use of modern inputs, practice better soil conservation techniques in order to boost production.

- Enactment of farmer's cooperatives or associations in order to create economics of scale and also to resist unfavourable marketing conditions usually imposed by the force of demand and supply of tomato.

- Extension agents should be provided and be sent to this area to assist the farmers in bridging information gap between the research stations and the farmers as regards new findings and education of the farmers so as to get enough training in reducing the effects of various constraints on the productivity of their production. Extension contact is a significant variable for improving efficiency. Policies designed to educate farmers through proper agricultural extension services could have a great impact on increasing the level of efficiency and hence agricultural productivity. Government should strengthen extension service delivery, employ more extension agents and motivate them adequately to reach out to the tomato farmers in the study area.

- Government should provide inputs such as chemical (pesticides and herbicides) planting seeds at subsidized rate to the farmers and aim at solving major constraints of farmers such as loan, provision of all season rural access roads, storage facilities.

- Farmers should be encouraged to use modern inputs and intensification of agriculture should be encouraged. Cooperate bodies and non-governmental bodies should still be encouraged to establish programmes in the study area to complements the efforts of the government.

- Considering the low yield of farmers in the last production which is more than average of the respondents identified the variation and reaction of soil to the tomato, more research work should be concentrated on the best alternatives method by which soil can be considered that can easily be developed locally so that yield dwindling would not be permanent. In addition, developing input markets, especially for fertilizer, herbicides and improve seeds is crucial. Government should allow and encourage full participation by private traders so as to improve the supply and distribution of inputs.

- Farmers should be encouraged to form cooperatives or join existing ones by government and nongovernmental organizations to enhance their access to credit facilities and enjoy economics of scale in procuring farm inputs as well as selling their farm produce in bulk.

\section{References}

[1]. Awudu, A. and Richard, E. (2001). Technical Efficiency During Economic Reforms inNicaragua: Evidence From Farm Holds Survey Data. Economic Systems 25: 113-125.

[2]. Ayinde, A.I., Akerele, D and Ojeniyi, O.T (2011). Resource use Efficiency and Profitability ofFluted Pumpkin Production under Tropical Conditions. International journal of vegetable science. 17 (1):75-82

[3]. Ajibefun, I. A. (2002). “Analysis of Policy Issues in Technical Efficiency of Small Scale FarmersUsing the Stochastic Frontier Production Function".With Application to Nigerian Farmers". Paper Prepared for presentation at the international farm Management association congress, Wageningen, Netherland.

[4]. Ajibefun, I.A., Battese, G.E. and Daramola, A.G. (2002). Determinants of Technical Efficiency in Small Holder Crops Farming: Application of Stochastic Frontier Production Function: Quarterly Journal of International Agriculture 41(3): 225 - 240.

[5]. CBN Economic and Financial Review Vol. 37 No. 3 (The Complete Book) Published 9/30/1999. VOL. 37 NO. 3

[6]. FAO (2007) Production Year Book, Food and Agriculture Organization, Rome, Italy.Food and Agriculture Organization (FAO) (2003).FAO FAOSTAT http://faostata.fao.org/default.htm. Retrieved 4.2.2009

[7]. Gani, B.S. and Omonona, B.T. (2009): Resource-Use Efficiency among small-scale Irrigated maize Producers in Northern Taraba State of Nigeria. Journal of Human Ecology.Vol. 27 No. 2 pp 113-119. Pakistan. 
[8]. Imoudu P. B, and Toluwase S. O. W (2005) "A Comparative Study of Agricultural Loans Recovery under the National Directorate of Employme (NDE) in Ondo State of Nigeria". Applied tropical Agriculture. Vol. 10, No. 2; Pp. 24-30.

[9]. Kibaara, B.W. (2005). Technical Efficiency in Kenya's Maize Production: An Application of the Stochastic Frontier Approach. Unpublished M.Sc. Thesis submitted to Department of Agricultural and Resources Economics, Colorado State University, Fort Collins, Colorado.

[10]. Liu, Z. and Zhuang, J. (2000). Determinants of Technical Efficiency in Post-Collective ChineseAgriculture: Evidence from FarmLevel Data. Journal of Comparative Economics28:545-564.

[11]. National Population Commission (NPC) 1991 Nigeria demographic figure

[12]. Olayide S.O and Heady E.O (1982).Introduction to agricultural Economics.Ibadan University Press.

[13]. Olukosi, J.O and Erhabor, P.O. (2005).Introduction to Farm Management Economics:Principles and Applications.Agitab Publishers Ltd, Samaru, Zaria, Nigeria.

[14]. Olukosi, J.O and Ogungbile, A.O. (1989).Agricultural Production Economics: Principles and Applications. Agitab Publishers Ltd, Samaru, Zaria, Nigeria.

[15]. Omonona, B.T.(2003) "Efficiency of Resource-Use in Cassava Production in Kogi State, Nigeria. Implications for Food Security and Environmental Degradation".Journal of Environmental Extension.Vol. 4 (December) pp 13-18

[16]. Shankara Naika, et al :Agromisa Foundation and CTA, Wageningen, 2005.AGRODOK 17, Cultivation of tomato production, processing and marketing. Pg. 6-8.

[17]. Yusuf, O., Sanni., S.A., Ojuekaiye,E.O and Ugbabe,O.O. (2008). Profitability of EgusiMelon(citrulluslanatusthumb.mansf) Production under Sole and Mixed CroppingSystems in Kogi State of Nigeria.ARPN Journal of Agriculture and Biological Science(2): 14-18. 